\title{
高中班主任班级管理的心理压力及解决策略研究
}

唐雪玲

广西省梧州市岑溪市第七中学

DOI:10.32629/jief.v2i4.1306

[摘 要] 高中阶段对于学生来说具有不同于其他学段的别样意义, 这源于他们将面对的人生转折点, 源于这个年龄段特有的心理状态。而高 中班主任作为学校教育中的重要角色, 与学生相处时间长, 对于学生的学习会发挥重要作用。随着教育理念和方针的变化, 社会與论对高中 班主任提出了很高的要求，这使得高中班主任压力很大。本文将探讨高中班主任的心理压力问题，并就此问题提出一些解决策略。

[关键词] 高中班主任; 压力; 解决策略

中图分类号: G631 文献标识码: A

随着新课标教育改革如火如茶的进行, 对于高中班主任提出了多样 化的要求, 既要求高中班主任融汇并贯彻最新教育理念, 关注学生的心 理, 同时也要求班主任督促提高学生成绩, 故而高中班主任在管理班级 时压力来源较多。加之当下处于信息化时代, 高中班主任的一举一动都 会受到社会的关注。本文便是试图分析引发高中班主任压力的来源因素, 并寻求相关解决途径, 为减缓高中班主任压力提供思路。

\section{1 高中班主任心理压力来源分析}

\section{1 工作内容繁复}

高中班主任责任重大的一个表现在于, 不仅仅要承担普通任课教师 的工作量, 包括备课、上课、布置作业、批改作业、解答疑问等, 同时 还必须扮演好高中班主任的角色, 履行高中班主任的职责。比如监督学 生的早晚自习、随时了解学生的心理状况和在校表现、制定班规、任命 班干部、将学校通知及时传达给学生、强调学生注意各种安全、调节学 生之间的矛盾等大大小小的事务。故而高中班主任的工作相对繁琐。

高中班主任这一职务决定了其面对的对象不仅仅是学生, 还有学校 的管理层以及校外学生的家长等。这样的现状仿佛将高中班主任置于一 个中心点上, 而不同的线索都将会找到班主任。比如说, 除了解决在校 学生的疑难情况时, 班主任还需要定时向学校汇报班级教务情况, 与学 校管理层及后勤处打交道。除此以外, 高中班主任在面对升学心切的学 生家长时, 还需要积极与家长沟通交流, 解答家长的疑惑。繁杂而多向 的工作内容使得高中班主任常常处于精神紧张的状态, 成为班主任心理 压力的一个重要来源。

1.2 新理念与传统旧观念的双重压力

针对当下中学教育现状, 教育部提出并贯彻了新的教学理念方针和 政策。其强调培养全面发展的学生, 不可仅仅关注学生的成绩, 要重视 培养学生的创新创造能力, 改变从前以教师为主体地位的教学情状, 将 学生放在首位。但由于该教育理念提出时间还较短, 真正贯彻落实下去 产生效果还需要等待一段时间, 且需要根据实践效果进行相应改进。加 之人们接受一种新理念都需要一定的缓冲期, 故而成绩优劣仍是衡量学 生的重要标准, 学生家长仍将成绩作为主要关注点, 学校也将升学率作 为着重发展点。基于此, 高中班主任面对教育新理念和传统旧观念的冲 突, 受到多重标准的要求和影响。高中班主任既要响应新的教育方针和 政策, 重视学生的全面发展, 同时还必须重点关注学生的考试成绩, 对 学校和家长负责, 这亦成为高中班主任压力大的一个重要来源。

1.3 外界关注度和期待值太高

此处的外界包含的内容有家长、社会與论等几个方面。一般来说, 外界衡量一个高中班主任是否合格的标准, 大多还是集中在其所在班级 学生的学习成绩情况。如果该班主任所管理班级学生的成绩普遍偏好, 被大众认可为所谓的培优班, 那么外界对于该班主任的评价便会偏高, 肯定其工作态度和成果。但一旦学生的成绩出现下降的趋势, 班级管理 出现一些小差错时, 外界第一反应便会将责任归结于班主任管理不尽心 或者是班主任管理教育方法不得当。出现这种情况时, 班主任可能会受 到家长的苛责, 也会受到学校管理层的询问, 并对班主任下一步的工作 进行一定程度上的干预。

除此以外, 班主任这一角色更像是学校和学生及家长之间的纽带, 班主任需要进行上传下达的工作。将学校的相关要求及决策传达给学生
及家长, 向其说明并解释具体缘由, 一旦要求不合学生或家长心意时, 班主任便会成为被为难被质疑的对象。长此以往, 班主任就处于学校和 学生之间的两难境地, 稍不注意便会引起其中一方不满。故而高中班主 任尽管工作内容繁杂, 但外在给予的关注度和期待值太高, 且舆论风向 变化快, 成为班主任压力的来源之一。

\section{2 减缓班主任心理压力的方法策略}

2.1 明确自身责任及角色

高中班主任首先必须明确自身责任及定位, 只有坚定自身角色, 明 确自身责任, 在面对外界反馈时亦能保持心态平稳。高中班主任既是一 名普通的任课教师, 故而需要做好本职内的工作, 按照要求备课、上课、 批改作业, 努力将知识传授给学生; 在作为一名班级管理者时, 就做好 管理者分内的工作, 制定班级规范制度, 善于和学生及家长沟通, 及时 了解学生情况等。这样的话, 有利于班主任在扮演不同的角色时, 能够 在各个角色中履行自己的职责而不是相互干扰, 最终达到班级管理情况 良好、教学任务顺利完成的效果。

2.2 转变心态提升抗压能力

高中班主任的角色决定了其工作内容的繁杂性以及外界持续的关注 度和期待值。故而高中班主任要学会提高工作效率, 转变固有心态以提 升抗压能力。比如高中班主任可以通过学懂教育新理念, 更好的消化教 育方针及政策, 以便在实际教学及管理工作中灵活运用多种方法。高中 班主任还可以通过阅读相关教育书籍, 拓宽眼界, 开拓思维, 向经验老 道的高中班主任学习取经。通过多种途径的学习和改进, 高中班主任自 身的能力和心态都会发生好的转变, 从而提升其抗压能力。

2.3 塑造良好的理解氛围

减缓高中班主任的心理压力当然需要其自身的付出与转变, 但与此 同时, 作为高中班主任压力重要来源的外界, 也需要进行改进, 给班主 任提供一个相对轻松和宽容的與论环境。故而对于高中班主任的工作, 外界要尽量多一些理解和包容, 不要过分苛责。学生的学习成绩固然与 班主任的职责有关, 但同时还受其他因素的影响, 在学生成绩降低时不 能仅仅将责任归于高中班主任, 同时家长也要正确看待学生成绩的正常 起伏波动。同时学校也要给予班主任适度的自由空间, 为班主任的工作 提供支持和肯定。

3 结束语

在应试教育大背景和教育新理念提出的当下, 高中班主任由于工作 内容繁杂, 教育新旧观念冲突, 外界與论影响大等因素, 造成其心理压 力大, 甚至影响了正常教学和管理工作。故而从多方面减缓高中班主任 压力刻不容缓, 这有助于提升班主任教学及管理效率, 实现学生、家长、 学校、教师的良性循环关系。

\section{[参考文献]}

[1]杨云霞.高中班主任管理风格对班级凝聚力的影响 [J]. 新课 程,2020(33):227.

[2]杨艳元.浅谈新形势下高中班主任的班级管理艺术[J].考试周 刊,2020(70):163-164.

[3]杨小伟.自媒体时代下高中班主任的班级管理实践 [J]. 天津教 育,2020(21):34-35. 